\title{
EFFECT OF INTRATHECAL NALBUPHINE AND MAGNESIUM SULPHATE USED AS ADJUVANTS WITH BUPIVACAINE IN SPINAL ANAESTHESIA FOR LOWER ABDOMINAL SURGERY: A COMPARISON
}

\author{
Biswadeep Choudhury1, Deba Gopal Pathak2, Ram Chandraji Chauhan³ , L. Chandralekha Singha4, Debashish Mondal ${ }^{5}$
}

1 Postgraduate, Department of Anaesthesiology, Silchar Medical College and Hospital.

2 Professor and HOD, Department of Anaesthesiology, Silchar Medical College and Hospital.

3 Postgraduate, Department of Anaesthesiology, Silchar Medical College and Hospital.

${ }_{4}^{4}$ Postgraduate, Department of Anaesthesiology, Silchar Medical College and Hospital.

5 Postgraduate, Department of Anaesthesiology, Silchar Medical College and Hospital.

\section{ABSTRACT}

\section{BACKGROUND}

Nalbuphine, a semi-synthetic, mixed agonist-antagonist opioid, has a potential to attenuate the mu-opioid effects and to enhance the kappa-opioid effects. The use of different adjuvants including Nalbuphine with local anaesthetics extends the duration of surgical anaesthesia including postoperative analgesia.

\section{METHODS}

Randomised, double blinded, case control study conducted in 100 adult ASA I and II patients divided randomly into two groups of 50 each undergoing lower abdominal surgeries Group M received (100 mg/0.2 mL) 50\% preservative free Magnesium Sulfate and Group N received $(0.8 \mathrm{mg} / 0.2 \mathrm{~mL}) \quad 0.4 \%$ Nalbuphine along with $3 \mathrm{~mL}$ of $0.5 \%$ heavy bupivacaine each intrathecally.

\section{RESULT}

The onset of $\mathrm{T} 10$ sensory block $5.75 \pm 0.74 \mathrm{~min}$. in group $\mathrm{M}$ and $4.20 \pm 0.67 \mathrm{~min}$. in group $\mathrm{N}$, which is significantly faster in group $\mathrm{N}(\mathrm{p}<0.0001)$. Time of regression to S1 sensory level is $199.44 \pm 10.41 \mathrm{~min}$. in group $\mathrm{M}$ and $154.84 \pm 8.11 \mathrm{~min}$. in group $\mathrm{N}$, which is prolonged in group $\mathrm{M}(\mathrm{p}<0.0001)$. The mean time for rescue analgesia in group $\mathrm{M}$ is $241.06 \pm 19.61$ minutes and group $\mathrm{N}$ is $257.30 \pm 28.50 \mathrm{~min}$., which is statistically significant ( $\mathrm{P}$ value=0.0013), i.e. prolonged postoperative analgesia in group $\mathrm{N}$.

\section{CONCLUSION}

Nalbuphine has faster onset of anaesthesia and provides prolonged postoperative analgesia compared to magnesium sulphate when used as adjuvants with bupivacaine in spinal anaesthesia.

\section{KEYWORDS}

Intrathecal, Nalbuphine, Magnesium Sulphate, Postop Analgesia.

HOW TO CITE THIS ARTICLE: Choudhury B, Pathak DG, Chauhan RC, et al. Effect of intrathecal nalbuphine and magnesium sulphate used as adjuvants with bupivacaine in spinal anaesthesia for lower abdominal surgery: a comparison. J. Evolution Med. Dent. Sci. 2016;5(68):4922-4926, DOI: 10.14260/jemds/2016/1118

\section{INTRODUCTION}

Pain is "an unpleasant sensory and emotional experience associated with actual or potential tissue damage or described in terms of such damage."(1)

Regional anaesthesia is a safe, effective and inexpensive anaesthesia with an added advantage of long duration of postoperative analgesia. With epidural block, catheter have been used to produce prolonged postoperative analgesia while with spinal anaesthesia many adjuvants are used with local anaesthetic agent to increase the total duration of effective analgesia. Magnesium sulphate blocks NMDA channels in a voltage dependent fashion and such NMDA antagonism can prevent the induction of central sensitisation from peripheral nociceptive stimulation. (2)

Nalbuphine, a semi-synthetic, mixed agonist-antagonist opioid, has a potential to attenuate the mu-opioid effects and

Financial or Other, Competing Interest: None.

Submission 15-07-2016, Peer Review 08-08-2016,

Acceptance 13-08-2016, Published 25-08-2016.

Corresponding Author:

Dr. Ram Chandraji Chauhan,

C/o-Department of Anaesthesiology,

Silchar Medical College and Hospital,

Ghungoor, Silchar,

Cachar-788014,

Assam.

E-mail: chandra05ram@gmail.com

DOI: $10.14260 /$ jemds/2016/1118 to enhance the kappa-opioid effects. It was synthesised in an attempt to produce analgesia without the undesirable side effects of a $\mu$ opioid receptor agonist. Previous studies have shown that epidural or intrathecal administration of Nalbuphine produces a significant analgesia accompanied by minimal pruritus and respiratory depression. $(3,4,5)$ Culebras et al in 2002 used intrathecal Nalbuphine in doses $0.2,0.8$ and 1.6 mg with $10 \mathrm{mg}$ of $0.5 \%$ hyperbaric Bupivacaine in patients undergoing caesarean section under Subarachnoid Block (SAB) and found $0.8 \mathrm{mg}$ of Nalbuphine as an effective dose.(6) This study was undertaken to evaluate efficacy of intrathecally administered Bupivacaine with Magnesium sulphate and Bupivacaine with Nalbuphine for onset and duration of sensory and motor block, haemodynamic stability, duration of effective analgesia including postop analgesia and any adverse effects with each combination in patients undergoing lower abdominal surgeries.

\section{BACKGROUND}

The use of different adjuvants with local anaesthetics extends the duration of surgical anaesthesia including postoperative analgesia.

\section{AIMS AND OBJECTIVES OF THE STUDY}

This study was conducted to evaluate the effect of Magnesium sulfate and Nalbuphine when added to Bupivacaine for 
instituting central neuraxial block. In group M Magnesium Sulphate and in group N Nalbuphine was taken as adjuvant with Bupivacaine to produce Central neuraxial block. Both these groups were compared.

- To compare the onset of sensory and motor block.

- To compare the duration of sensory and motor block.

- To assess the duration of postop analgesia obtained in both the groups.

- To compare preop and postop haemodynamic changes and side effects.

\section{MATERIAL AND METHODS}

The prospective, double blinded, randomised case control study was conducted within a period of 6 months from 1st December 2015 to 30th May 2016 in 100 adult ASA I and II patients divided randomly into two groups of 50 each undergoing lower abdominal surgeries after approval from Hospital Ethical Committee of Silchar Medical College and Hospital. After obtaining written and informed consent, Group $M$ received (100 mg/0.2 $\mathrm{mL}) 50 \%$ preservative free Magnesium Sulphate and Group N received $(0.8 \mathrm{mg} / 0.2 \mathrm{~mL})$ $0.4 \%$ Nalbuphine along with $3 \mathrm{~mL}$ of $0.5 \%$ heavy Bupivacaine each intrathecally. Total volume of drug in both the groups was $3.2 \mathrm{~mL}$. Sensory and motor block characteristics were studied. Duration of rescue analgesia noted and any side effect observed. Data analysed by GraphPad InStat software using appropriate statistical test. For qualitative data, chi-square test was used. Quantitative data were analysed using student's t-test.

The $P$ value was determined.

- $P>0.05$ is not significant.

- $\mathrm{P}<0.05$ is significant.

- $\mathrm{P}<0.001$ is highly significant.

Following observations were made during the course of the study.

\section{STUDY PROTOCOL}

\section{Preanaesthetic Assessment}

- Detailed preoperative evaluation including history, investigations and physical examination done on the previous day of surgery.

- Procedure explained to the patient and patient was informed to communicate about the perception of any intraoperative discomfort or pain.

- Explained about VAS score.

- Written informed consent was taken from the patients and his/her relatives.

\section{Equipment}

Equipment used in the study consist of:

- An autoclaved tray containing instruments used for antiseptic draping.

- Disposable 23G lumbar puncture needle.

- Disposable 5 cc syringe.

- Disposable tuberculin syringe.

\section{Drugs}

- Inj. Bupivacaine $0.5 \%$ heavy ampoule.

- Inj. Magnesium sulphate 50\% preservative free ampoule.
- Inj. Nalbuphine $1 \%$, which was made as $0.4 \%$ by diluting its $1 \mathrm{~mL}$ to $2.5 \mathrm{~mL}$ with distilled water.

\section{In the Operation Theatre}

- IV line secured and each patient were preloaded with 15 $\mathrm{mL} / \mathrm{kg}$ of Ringer's lactate solution before procedure.

- Pulse oximeter, noninvasive blood pressure monitoring and ECG were attached and baseline reading taken.

\section{Technique}

- Under all strict aseptic and antiseptic precaution with patient in left lateral position, lumbar puncture was performed at L2-L3 intervertebral space with 23G Quincke's needle and selected drug was given slowly after free flow of clear CSF. After completion of procedure, patient was immediately turned to supine position.

- Pulse, BP, SPO2 and RR were recorded Preoperatively and every $1,5,10,15,30,45$ and 60 minutes after giving spinal anaesthesia and then 1 hourly for 6 hours postoperatively.

\section{Evaluation}

- The onset and duration of sensory blockade was assessed by using pinprick test every 1 minute till 15 minutes. Then, at 20,30, 45 and 60 minutes and then every 30 minutes till completion of surgery.

- Time required for sensory block to reach level T10 dermatome level was considered as sensory onset.

- Motor blockade was assessed by modified Bromage score.

- Time for onset of grade 3 motor blockade was noted.

- After establishment of adequate level of block, surgery was started and time of beginning of surgery was noted.

- Intravenous fluid was administered depending on the weight of patient and adjusted according to surgery.

- Time for sensory regression to S1 dermatome level was noted.

- Time for motor regression to Bromage 0 was noted.

- The duration of effective analgesia was considered as time from intrathecal injection to administration of rescue analgesia.

- A VAS score of 4 was considered as time for regional anaesthesia and the time noted.

- Patients were watched for any intraoperative complications like bradycardia, hypotension, sedation, nausea, vomiting, dryness of mouth, pruritus and respiratory depression.

- Hypotension was defined as MAP $>20 \%$ decrease from baseline value.

- Tachycardia was defined as heart rate $>100 /$ mins. and bradycardia was defined as heart rate $<60 / \mathrm{mins}$.

\section{RESULTS AND OBSERVATIONS}

Demographic Characteristics of the Patients in the Two Groups

\begin{tabular}{|l|c|c|c|}
\hline Variables & No. of Patients & Mean & SD \\
\hline Group M & 50 & 43.72 & 9.66 \\
\hline Group N & 50 & 40.79 & 10.45 \\
\hline \multicolumn{3}{|c|}{ Table 1: Distribution of Age (in Years) between Two } \\
Groups \\
\hline
\end{tabular}

$\mathrm{P}=0.1490$ 
Table 1 shows age distribution in each group. All the patients participating in the study were in age of 20 to 60 years. On statistical comparison using unpaired $t$ test, $P$ value was found to be $>0.05$. Hence, the two groups were comparable and non-significant.

\begin{tabular}{|c|c|c|c|c|}
\hline Variables & $\begin{array}{c}\text { No. of } \\
\text { Patients }\end{array}$ & Male & Female & $\begin{array}{c}\text { P } \\
\text { value }\end{array}$ \\
\cline { 1 - 4 } Group M & 50 & $\begin{array}{c}18 \\
(36 \%)\end{array}$ & $\begin{array}{c}32 \\
(64 \%)\end{array}$ & \multirow{2}{*}{0.42} \\
\cline { 1 - 3 } Group N & 50 & $\begin{array}{c}15 \\
(30 \%)\end{array}$ & $\begin{array}{c}35 \\
(70 \%)\end{array}$ & \\
\hline \multicolumn{4}{|c|}{ Table 2: Sex Distribution } \\
\hline
\end{tabular}

Table 2 shows sex distribution of both the groups. 100 patients of either sex had participated in this study. Using chisquare test, both the groups were found to be comparable and non-significant.

\begin{tabular}{|c|c|c|c|c|}
\hline Variables & $\begin{array}{c}\text { No .of } \\
\text { Patients }\end{array}$ & Mean & SD & $\begin{array}{c}\text { P- } \\
\text { value }\end{array}$ \\
\hline Group M & 50 & 155.04 & 6.20 & \multirow{2}{*}{0.39} \\
\hline Group N & 50 & 154.11 & 4.5232 & \\
\cline { 1 - 2 } Table 3: Distribution of Height (in cm) \\
in the Two Groups \\
\hline
\end{tabular}

Table 3 shows distribution of height in each group. On statistical comparison using unpaired student's $t$ test, the $P$ value was found to be $>0.05$. Hence, the two groups were comparable and non-significant.

\begin{tabular}{|c|c|c|c|c|}
\hline Variables & No. of Patients & Mean & SD & P-value \\
\hline Group M & 50 & 50.69 & 6.11 & \multirow{2}{*}{0.15} \\
\hline Group N & 50 & 52.36 & 5.34 & \\
\cline { 1 - 4 } Table 4: Distribution of Body Weight (in Kilograms) in \\
the Two Groups \\
\hline
\end{tabular}

Table 4 shows distribution of body weight in each group. On statistical comparison, using unpaired student's $t$ test, the

On statistical comparison, using unpaired student's t test, the
\begin{tabular}{|c|c|c|c|}
\hline Variable & $\begin{array}{c}\text { Group M (Mean } \pm \text { Standard } \\
\text { Deviation) }\end{array}$ & $\begin{array}{c}\text { Group N (Mean } \pm \text { Standard } \\
\text { Deviation) }\end{array}$ & P value \\
\hline Time to reach T10 sensory block (min.) & $5.75 \pm 0.74$ & $4.20 \pm 0.67$ & $<0.0001$ \\
\hline Time to reach highest level of sensory block (min.) & $18.25 \pm 1.83$ & $18.74 \pm 0.98$ & 0.0991 \\
\hline Time to reach Bromage-3 (min.) & $7.54 \pm 1.18$ & $5.33 \pm 0.41$ & $<0.0001$ \\
\hline Regression time to S1 dermatome (min.) & $199.44 \pm 10.41$ & $154.84 \pm 8.11$ & $<0.0001$ \\
\hline Regression time to reach Bromage 0 (min.) & $175.6 \pm 9.27$ & $133.62 \pm 15.88$ & $<0.0001$ \\
\hline Time for rescue analgesia (min.) & $241.06 \pm 19.6$ & $257.30 \pm 28.50$ & 0.0013 \\
\hline Table 8: Comparison of Subarachnoid Block Characteristics between Magnesium and Nalbuphine Group \\
\hline
\end{tabular}

Table 8 shows the onset time T10 sensory and motor blockade were significantly prolonged in Group M .Time for sensory and motor regression were prolonged in Group $\mathrm{M}$, but duration of effective analgesia were prolonged in Nalbuphine group as compared to Magnesium group.

\begin{tabular}{|c|c|c|c|}
\hline Adverse Effects & Groups & Incidence & P-value \\
\hline \multirow{2}{*}{ Nausea } & $\mathrm{M}$ & $2(4 \%)$ & \multirow{2}{*}{$>.05$} \\
\cline { 2 - 3 } & $\mathrm{N}$ & $3(6 \%)$ & \\
\hline \multirow{2}{*}{ Vomiting } & $\mathrm{M}$ & 0 & \multirow{2}{*}{$>.05$} \\
\cline { 2 - 3 } & $\mathrm{N}$ & $1(2 \%)$ & \multirow{2}{*}{$>.05$} \\
\cline { 2 - 3 } Bradycardia & $\mathrm{M}$ & $8(16 \%)$ & \\
\cline { 2 - 3 } & $\mathrm{N}$ & $11(22 \%)$ & \multirow{2}{|c}{} \\
\hline
\end{tabular}

$\mathrm{P}$ value was found to be $>0.05$. Hence, two group were comparable and non-significant.

\begin{tabular}{|c|c|c|c|c|}
\hline Variables & $\begin{array}{c}\text { No. of } \\
\text { Patients }\end{array}$ & ASA 1 & ASA 2 & $\begin{array}{c}\text { P } \\
\text { value }\end{array}$ \\
\cline { 1 - 4 } Group M & 50 & $32(64 \%)$ & $\begin{array}{c}18 \\
(36 \%)\end{array}$ & \multirow{2}{*}{0.37} \\
\cline { 1 - 3 } Group N & 50 & $35(70 \%)$ & $\begin{array}{c}15 \\
(30 \%)\end{array}$ & \\
\cline { 1 - 3 } Table 5: Distribution of Patients in Groups According to \\
ASA Physical Status 1 and 2 Status \\
\hline
\end{tabular}

Table 5 shows distribution of patients in groups according to ASA 1 and 2. On statistical comparison using chi-square test, $\mathrm{P}$ value was found to be $>0.05$. Hence, the groups were comparable and non-significant.

\begin{tabular}{|c|c|c|c|c|}
\hline Variables & No. of Patients & Mean & SD & P-value \\
\hline Group M & 50 & 70.33 & 11.12 & \multirow{2}{*}{0.36} \\
\hline Group N & 50 & 68.05 & 13.80 & \\
\cline { 1 - 3 } Table 6: Comparison of Duration of Surgery (in min.) \\
\hline
\end{tabular}

Table 6 shows distribution of duration of operation (in minutes) between the two groups. On statistical comparison using unpaired t test, $\mathrm{P}$ value was found to be $>0.05$. Hence, comparable and non-significant.

\begin{tabular}{|c|c|c|c|c|}
\hline \multirow{2}{*}{$\begin{array}{c}\text { Proposed } \\
\text { Surgery }\end{array}$} & \multicolumn{2}{|c|}{ Group M } & \multicolumn{2}{c|}{ Group N } \\
\cline { 2 - 5 } & $\begin{array}{c}\text { No. of } \\
\text { Patients }\end{array}$ & $\mathbf{\%}$ & $\begin{array}{c}\text { No. of } \\
\text { Patients }\end{array}$ & $\%$ \\
\hline $\begin{array}{c}\text { Total abdominal } \\
\text { hysterectomy }\end{array}$ & 7 & $14 \%$ & 10 & $20 \%$ \\
\hline Vaginal hysterectomy & 11 & $22 \%$ & 8 & $16 \%$ \\
\hline Herniorrhaphy & 1 & $2 \%$ & 6 & $12 \%$ \\
\hline Hernioplasty & 8 & $16 \%$ & 4 & $8 \%$ \\
\hline Haemorrhoidectomy & 0 & 0 & 1 & $2 \%$ \\
\hline Subtotal hysterectomy & 2 & $4 \%$ & 4 & $8 \%$ \\
\hline Appendectomy & 20 & $40 \%$ & 17 & $34 \%$ \\
\hline Table 7: Comparison of Different Type of Operation \\
\hline
\end{tabular}

$P$ value $=0.43$ using chi-square test .

There is no significant difference in distribution of types of operation between the two groups. 
Table 9 adverse effect between two groups were comparable and statistically non-significant using Chi-Square Test.

\section{DISCUSSION}

With more than 100 years of use, neuraxial anaesthesia has enjoyed much success and endured controversy. The ease of performance and versatility of spinal anaesthesia has resulted in its widespread popularity in both hospital and ambulatory surgical applications. Spinal anaesthesia is a safe and effective alternative to general anaesthesia when the surgical site is located on the lower extremities, perineum (e.g., surgery on the genitalia or anus), or lower abdominal wall (e.g., inguinal herniorrhaphy). Caesarean section deliveries are routinely performed under spinal anaesthesia as are total hip arthroplasty and total knee arthroplasty.

To improve the spinal anaesthetic efficacy, adjuvants from different pharmacological classes of drugs are used to enhance and prolong analgesia to lower-dose requirements and to reduce dose-dependent side effects of local anaesthetics. Opioids, first and foremost have attained an integral role as a spinal anaesthetic adjuvant. (7)

There are numerous experimental data that provide evidence that N-methyl-D-aspartate (NMDA) receptors play a significant role in neuronal plasticity and processes leading to central sensitisation to pain. NMDA antagonists have shown efficacy in the reduction of acute postoperative pain and analgesic consumption. Intrathecal Magnesium can be considered as a physiological blocker of NMDA receptors at dorsal horn thus preventing central sensitisation to pain. There are studies where Magnesium has been administered by different routes such as intravenous, intrathecal, or via epidural that improved anaesthetic and analgesic quality.(8) In the present study, we compared the effect of addition of intrathecal Nalbuphine and intrathecal Magnesium sulfate to bupivacaine spinal block. The onset of T10 sensory block $5.75 \pm 0.74 \mathrm{~min}$. in group $\mathrm{M}$ and $4.20 \pm 0.67 \mathrm{~min}$. in group $\mathrm{N}$, which is significantly faster in Nalbuphine group ( $<<0.0001)$. Time of regression to S1 sensory level is $199.44 \pm 10.41 \mathrm{~min}$. in group $\mathrm{M}$ and $154.84 \pm 8.11 \mathrm{~min}$. in group $\mathrm{N}$. The sensory regression time is significantly prolonged in magnesium group $(\mathrm{p}<0.0001)$.

The characteristic of sensory block in our study is more or less similar to other studies with intrathecal Nalbuphine or magnesium sulfate when used as adjuvants with intrathecal bupivacaine in spinal anaesthesia. Ozalevli et al(9) observed similar delay in onset of $\mathrm{T}_{10}$ sensory analgesia on addition of Magnesium sulfate in Bupivacaine-fentanyl spinal anaesthesia. Sunil BV et al(10) in 2013 in his study found similar delay in onset of sensory block $6.46 \pm 1.32$ minutes. He also observed the Sensory regression time in Magnesium group is $(236.6+34.5)$ minutes, which is slightly prolonged than our studies. Marzieh-Beigom Khezri et al(11) in 2011 conducted study on 90 patients undergoing lower limb orthopaedic surgery. Patient in magnesium group received $3 \mathrm{~mL}$ of $0.5 \%$ bupivacaine plus $0.5 \mathrm{~mL}$ of $10 \%$ magnesium sulfate. The T10 sensory onset in Magnesium group is $5.86 \pm 1.25 \mathrm{~min}$., which is comparable with our studies, sensory regression time $132.06 \pm 11.47 \mathrm{~min}$. in Magnesium group and the sensory regression is quicker than our study. Dr. Charu J. Pandya et al(12) in 2013 conducted study on 60 patients undergoing lower abdominal study. They were divided into two groups of
30 each. Both group received drugs similar to our study. Onset of T10 sensory block is $5.1 \pm 0.8$ minutes in Magnesium group. The results were comparable with our study. Sensory regression is also similar to our study.

Jyothi B et al(13) in 2014 conducted a study on 100 patients undergoing lower limb and lower abdominal surgeries, they were divided into four groups A, B, C, D; each group receiving $3 \mathrm{~mL}$ of $0.5 \%$ heavy bupivacaine with $0.5 \mathrm{~mL}$ of normal saline, $0.8 \mathrm{mg}, 1.6 \mathrm{mg}$ and $2.4 \mathrm{mg}$ Nalbuphine with normal saline (total volume $3.5 \mathrm{~mL}$ ), respectively, injected intrathecally. The time to onset of sensory blockade in the group injected with $0.8 \mathrm{mg}$ of Nalbuphine was found to be $3.3 \pm 0.8 \mathrm{~min}$., which was comparable with our study. In a study conducted by Gomaa et

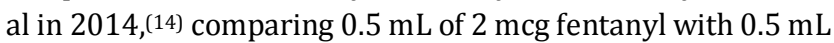
of $0.8 \mathrm{mg}$ nalbuphine with $2 \mathrm{~mL}$ of $0.5 \%$ hyperbaric bupivacaine. The time of onset of sensory block was found to be $1.64 \pm 0.09 \mathrm{~min}$. and $1.60 \pm 0.10 \mathrm{~min}$., respectively. The difference in the results with our study may be attributed to difference in the demographic profile of the patients selected for the study. The type of operation conducted (caesarean section) as well as the different drug dosage used keeping in mind the demography of the patients. In a study conducted by Mukherjee et al in 2011(15) with 0.8 mg intrathecal Nalbuphine, the time for sensory regression to $\mathrm{S} 1$ was found to be $153.3 \pm 6.05 \mathrm{~min}$. In another study conducted by HM Gomaa et al in $2014,(14)$ the time for sensory regression to S1 was $123.00 \pm 5.66 \mathrm{~min}$. While Patwa et al(16) found the sensory regression to $\mathrm{S} 1$ to be $98.16 \pm 9.86 \mathrm{~min}$. after injecting $0.5 \% 15$ mg heavy bupivacaine (3 mL) with $1 \mathrm{mg}$ of Nalbuphine $(0.5 \mathrm{ml})$.

In our study, onset of Bromage grade 3 motor blockade $7.54 \pm 1.18 \mathrm{~min}$. in magnesium group and $5.33 \pm 0.41$ in Nalbuphine group, regression of motor blockade 175.6 \pm 9.27 min. in magnesium group while $133.62 \pm 15.88$ in Nalbuphine group. In a study conducted by Dr. Charu J. Pandya et al(12) with intrathecal Magnesium Sulfate, the onset of Bromage grade 3 motor block is $7 \pm 1$ minutes and Bupivacaine group was $5.2 \pm 0.8$ minutes. Alem Wapang et al(17) in another study with intrathecal Magnesium sulfate found that onset of Bromage grade 3 motor block in Magnesium group was $8.00 \pm 1.29 \mathrm{~min}$. Sunil BV(10) et al in another study found the onset of Bromage 3 motor block to be $7.28 \pm 1.21$ minutes. The result of these studies were comparable with our study. Dr. Charu J. Pandya et $\mathrm{al}^{(12)}$ found the regression time to Bromage 0 was $175.25 \pm 7.69$ minutes. Alem Wapang et al(17) found the regression time to Bromage $0156.50 \pm 12.26$ minutes. The result of the above-mentioned studies were comparable with our study. In another study Marzieh-Beigom Khezri et al(11) found motor regression time to Bromage 0 was $118 \pm 14.65$ minutes, which is significantly less than our study.

In a study conducted by H. M. Gomaa et al(14) with intrathecal Nalbuphine, the time of onset of grade III motor blockade was found to be $5.72 \pm 0.17$ minutes. Similarly, in studies conducted by Mukherjee et al,(15) Sagar et al,(18) Shakooh et al,(19) the time of onset of grade III motor blockade was found to be $5.6 \pm 0.53$ minutes, $5.9 \pm 0.4$ minutes and $4.47 \pm 1.46$ minutes, respectively. In studies conducted by Mukherjee et al,(15) H.M Gomaa et al,(14) Sagar et al,(18) the duration of motor blockade was found to be $141.0 \pm 5.83$ minutes, $125.33 \pm 5.71$ minutes and $142.2 \pm 6.7$ minutes respectively, which are comparable with our observation. 
In our study, no patients required additional analgesics intraoperatively. Postoperative pain was assessed using a 10 cm Visual Analogue Scale (VAS) where '0' indicated 'No Pain' and ' 10 ' indicated 'worst imaginable pain'. The VAS score was recorded immediate postoperative $0 \mathrm{hrs}$. and at $1 \mathrm{hrs}$., $2 \mathrm{hrs}$., $3 \mathrm{hrs}$., $4 \mathrm{hrs}$., 5 hrs., 6 hrs. postoperatively. The mean time for rescue analgesia in Bupivacaine Magnesium group is $241.06 \pm 19.61$ minutes and nalbuphine group is $257.30 \pm 28.50$ min., which is statistically significant $(P$ value $=0.0013) \mathrm{Dr}$. Suhrita Paul et al(20) Marzieh-Beigom.

Khezri et al,11 M.P. Nath et al[21) 2012 found duration of effective analgesia with magnesium $382.13 \pm 46.9$ minutes, $318.33 \pm 74.62$ minutes and $291.4 \pm 18.6$ minutes respectively. The duration is significantly more than our studies and the results may be attributed to different demographical profile of the patients. The duration of effective analgesia in our study is comparable with the studies of Dr. Charu J. Pandya(12) et al, Alem Wapang et al.(17)

HM Gomaa et al, ${ }^{14}$ Mukherjee et al, ${ }^{15}$ Shakooh et al, ${ }^{19}$ Sagar et $\mathrm{al}^{18}$ and Patwa et $\mathrm{al}^{16}$ found the duration of analgesia in patients injected with intrathecal Nalbuphine to be $231.83 \pm 15.73$ minutes, $278.5 \pm 6.04$ minutes, $298.0 \pm 51.02$ minutes, $270.0 \pm 27.4$ minutes and $302.4 \pm 27.59$ minutes, respectively. They used $0.4 \mathrm{mg}$ to $1 \mathrm{mg}$ Nalbuphine intrathecally. The finding are comparable with our studies.

\section{CONCLUSION}

Nalbuphine has faster onset of anaesthesia and provides prolonged postoperative analgesia compared to magnesium sulphate when used as adjuvants with Bupivacaine in spinal anaesthesia.

\section{REFERENCES}

1. Merskey NB. A sample list of frequently used terms. International association for the study of pain task force on taxonomy. In: Merskey NB, ed. Classification of chronic pain. $2^{\text {nd }}$ edn. Vol. 2. Seattle: IASP Press 1994:209-14.

2. Miller R. Miller's anaesthesia. $7^{\text {th }}$ edn. Vol. 1. Philadelphia: Churchill Livingstone Elsevier 2010.

3. Eisenach JC, Carpenter R, Curry R. Analgesia from a peripherally active kappa opioid receptors agonist in patients with chronic pancreatitis. Pain 2003;101(1-2): 89-95.

4. Gutstein HB, Akil H. Opioid analgesics. In: Hardman JG, Limbird LE, eds. Goodman and Gilman's-the pharmacological basis of therapeutics. New York: McGraw Hill 2006:547-90.

5. Charuluxananan S, Kyokong O, Somboonviboon W, et al. Nalbuphine versus propofol for treatment of intrathecal morphine-induced pruritus after caesarean delivery. Anaesth Analg 2001;93(1):162-5.

6. Culebras X, Gaggero G, Zatloukal J, et al. Advantages of intrathecal nalbuphine compared with intrathecal morphine after caesarean delivery: an evaluation of postoperative analgesia and adverse effects. Anaesth Analg 2000;91(3):601-5.

7. Stoelting RK, Hillier SC. Pharmacology and physiology in anaesthetic practise. $4^{\text {th }}$ edn. Philadelphia: Lippincott Williams and Wilkins 2006.
8. Shrestha N, Gurung R, Marhatta MM. Pre-incisional epidural magnesium provides pre-emptive and postoperative analgesia in lower abdominal surgeries: a comparative study. Journal of Society of Anaesthesiologists of Nepal 2014;1(1):22-8.

9. Ozalevli M, Cetin TO, Unlugenc $\mathrm{H}$. The effect of adding intrathecal magnesium sulfate to bupivacaine-fentanyl spinal anaesthesia. Acta Anaesthesiologist Scand 2005;49(10):1514-9.

10. Sunil BV, Sahana KS. Comparison of dexmedetomidine and magnesium sulfate as adjuvants with hyperbaric bupivacaine for spinal anaesthesia. Journal of Medical Science and Clinical Research 2013;1(3):117-24.

11. Khezri MB, Yaghobi S, Hajhikani M, et al. Comparison of postoperative analgesic effect of intrathecal magnesium and fentanyl added to bupivacaine in patients undergoing lower limb orthopaedic surgery. Acta Anaesthesiol Taiwan 2012;50(1):19-24.

12. Pandya CJ. A comparative study of bupivacaine and bupivacaine with magnesium sulphate in spinal anaesthesia for lower abdominal surgery. IJSR 2013;2(7).

13. Jyothi B, Gowda S, Shaikh SI. A comparison of analgesic effect of different doses of intrathecal nalbuphine hydrochloride with bupivacaine and bupivacaine alone for lower abdominal and orthopaedic surgeries. Indian J Pain 2014;28(1):18-23.

14. Gomma HM, Mohamed NN, Zoheir HAH, et al. A comparison between postoperative analgesia after intrathecal nalbuphine with bupivacaine and intrathecal fentanyl with bupivacaine after caesarean section. Egyptian Journal of Anaesthesia 2014;30(4):405-10.

15. Mukherjee A, Pal A, Agrawal J, et al. Intrathecal nalbuphine as an adjuvant to subarachnoid block: what is the most effective dose? Anaesthesia, Essays and Researchers 2011;5(2):171-5.

16. Patwa AA, Endigeri A, Upadhay MR. A comparison of intrathecal nalbuphine hydrochloride with hyperbaric bupivacaine $0.5 \%$ and hyperbaric bupivacaine $0.5 \%$ alone in patients undergoing abdominal hysterectomy. Int J Res Med 2014:3(2);7-11.

17. Wapang A, Singh NR, Singh SS, et al. Effect of intrathecal dexmedetomidine and magnesium sulfate on the characteristics of bupivacaine spinal block. International Journal of Health Sciences and Research 2014;4(12):16977.

18. Sagar SM, Vishwas GK, Chiragbabu PS, et al. Comparison of efficacy of butorphanol and nalbuphine as intrathecal adjuvant to bupivacaine: a randomised double blind controlled study. JIARM 2013;1(6):527-32.

19. Shakooh S, Bhosle P. Intrathecal nalbuphine: an effective adjuvant for postoperative analgesia. Innovative Journal of Medical and Health Science 2014;4(2):79-82.

20. Paul S, Bhattacharjee DP, Ghosh S, et al. Efficacy and safety of intrathecal magnesium sulfate as an adjunct to bupivacaine for lower limb orthopaedic surgery. Pharmacologyonline 2009;2:570-4.

21. Nath MP, Garg R, Talukdar T, et al. To evaluate the efficacy of intrathecal magnesium sulfate for hysterectomy under subarachnoid block with bupivacaine and fentanyl: a prospective randomised double blind clinical trial Saudi Journal of Anaesthesia 2012;6(3):254-8. 